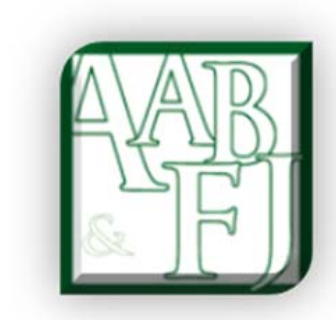

\title{
Lessons About Best Interests Duty
}

\section{Aaron Bruhn'1 \\ Michael Miller2}

\section{Abstract}

Financial advice is essentially a credence good, whose value is hard to assess. Yet in the Australian context the need for quality advice is growing, with self-sufficiency a growing trend and individuals facing significant complexity in their financial affairs. Recent regulatory proposals and reforms have been offered as a means to provide some comfort for consumers about the quality advice that they might receive, yet the challenge remains about what is meant by 'quality' in this area. By referring to recent high profile collapses, we describe some factors and features that are generally considered as examples of poor quality advice. In this manner, we offer bounds on what quality can be represented by, and outline factors that can be considered by individuals when assessing the quality of any service being offered.

JEL Classification: G38, D14, D18

Keywords: Best Interests Duty, Financial Planning, Wealth Management, Australia, Regulation

\footnotetext{
${ }^{1}$ Australian National University, aaron.bruhn@anu.edu.au

2 michael@mmillercfp.com.
} 


\section{INTRODUCTION}

Individuals face a number of financial and non-financial risks over their lifetime, especially concerning implications of longevity and adverse health. These risks can be exacerbated by a combination of complex rules and a large number of options for financial wellbeing, low levels of financial literacy, and a growing shift away from government- and employer- provided support towards greater self-sufficiency in retirement.

As such, the need for professional financial advice is apparent for many individuals. However, recent cases have highlighted the high levels of distrust that many people have in the delivery of such professional advice, complicating the provision of financial wellbeing further for those who would otherwise benefit from informed and impartial advice.

Recent regulatory proposals and debate have centred on various aspects of what constitutes 'good' advice, couched in terms of a 'best-interests' duty from the adviser to the customer. However, financial advice is essentially a credence good whose value is hard to assess, which presents a real challenge in being able to determine what is meant by 'quality' and 'best interests' in terms of advice.

By referring to recent events and in particular the high profile collapse of Storm Financial, we describe in this paper some features that are generally considered as examples of poor quality advice. We use a qualitative methodology, based on data sourced from a Parliamentary Inquiry, as well as interviews with ex-Storm advisers and investors. In doing so we offer bounds on what quality can be represented by, and outline factors that can be considered by individuals when assessing the quality of any advice being offered.

\section{THE CONTEXT OF FINANCIAL PROVISION IN AUSTRALIA}

In this section we outline the main features of the Australian system of financial provision, particularly in regard to saving and living throughout retirement. We begin with an overview of the 'system of pillars' of retirement saving, and then discuss the issues of complexity, the trend to self-sufficiency, and the importance of and shortfalls in financial literacy.

\section{A system of pillars}

Financial security in Australia, in the context of savings and provision over a lifetime and particularly for retirement, is essentially built on a system of 'pillars'. The first of these is an age pension, which is subject to two means tests - one based on assets, the other based on income. The pension payment is at the rate which is the lower that results from each of these two tests, with the full age pension rate generally accepted to be close to a rate that could provide for a modest lifestyle (RWA 2012). A second pillar is a mandatory retirement savings scheme, paid as employer contributions that are currently a minimum of $9.5 \%$ of salary. Pillar three consists of voluntary and private savings, with any contributions at the discretion of individuals, and/or employers. Via the use of advantageous tax breaks, there is strong encouragement for these extra savings to be allocated into superannuation accounts (Taylor and Wagland 2011).

Alongside the growth of superannuation savings arising from the SG has been the decline in employer-sponsored defined benefit (DB) schemes. In contrast to DB schemes, the SG is primarily a defined contribution (DC) system, which specifies the level of contributions made to an individual's superannuation fund(s). Investment choices reside with the individual and with 
no pensionable income being specified, the 'sufficiency' of a DC scheme in terms of retirement income is not a responsibility of sponsors.

\section{Complexity, choice and self-sufficiency}

The Australian financial system is considered to be very complex, due to many factors relating to tax; changes and choices within superannuation and its interaction with the other pillars; insurance options and platforms ${ }^{3}$; the structuring of debt arrangements ${ }^{4}$; and aged care provision which depends on factors such as assets, income, and the required standard of care (Chardon 2011, McKee 2010, RWA 2012). Such complexity is also prevalent in other countries, and is given much attention by various commentators (for example, Bodie et al. 2008, MacDonald et al. 2011, Warren 2006).

The fact that various aspects of the pillars and their interaction have changed over time and/or have been signalled that they may change in the future complicates the picture further ${ }^{5}$. Of particular interest is the requirement for individuals to be actively involved in making a range of choices for their financial wellbeing. In DC schemes choices must be made concerning fund and investment allocations whilst saving, as well as how to manage and utilise these savings whilst in retirement (Beshears et al. 2011, Bodie et al. 2008, Gallery et al. 2011, MacDonald et al. 2011). The availability of choice for individuals is considered effective only if individuals appreciate and can make appropriate investment and risk-related decisions (Bateman et al. 2010; 2011a), as much more risk now has to be absorbed at an individual rather than collective level (Warren 2006).

A consequence is the need for individuals to now be far more self-sufficient for their overall financial wellbeing, particularly in Australia (Smith 2009). This does not just apply to how and through what mechanisms an individual can save for retirement - though this is clearly important - but the more encompassing issue is how they provide for their requirements over an entire lifetime. This is more an issue of smoothing one's income earned whilst working, and indeed, is the central question of life-cycle finance (Siegel 2008). It infers a lifetime of responsibility on the individual for decisions relating to all of saving, investing, and spending (Bodie et al. 2008, Lusardi and Mitchell 2011).

\section{Financial literacy}

One definition of financial literacy is 'the ability to make informed judgments and to take effective decisions regarding the use and management of money' (ASIC 2003), which requires an individual to make decisions and modify their behaviours in a way that is financially advantageous to them (Chardon 2011). This includes planning over longer rather than shorter time periods (Campbell 2006), making appropriate choices regarding superannuation funds and investment options (Gallery et al. 2011), having a working appreciation of the time value of

\footnotetext{
${ }^{3}$ The primary options in terms of personal coverage concern life, total and permanent disablement, trauma, income protection cover, health and general insurances, with some life insurances available within as well as outside of superannuation.

${ }^{4}$ This includes house, car, investment, and personal loans, credit cards, and other consumer purchase arrangements such as hire purchase.

${ }^{5}$ For example, the age of eligibility for the Age Pension is to increase to 67 progressively from 2017, and this itself will be reviewed again in 2023 (RWA 2012).
} 
money, and appreciating the advantages of risk pooling mechanisms such as with insurance (Fear 2008).

What is apparent is that despite today's world of financial choice, complexity and selfreliance, levels of financial literacy are generally considered to be low, given the responsibility that individuals must bear (Iannicola and Parker 2010, Widdowson and Hailwood 2007) ${ }^{6}$. It is specifically in the area of risk where a lack of financial literacy is particularly apparent (Bateman et al. 2011b, Lusardi and Mitchell 2011, Smith 2009).

Whilst many researchers, policymakers, industry commentators and the industry itself may bemoan a general lack of financial literacy, perhaps it is not surprising that such levels of financial literacy exist. One reason is that although people have familiarity with money, there are limitations to what can be learned from one's own financial experiences. This is because each person only goes through each life stage once, and when decisions relate to a long term horizon it is often difficult to assess the worth or otherwise of such decisions. Furthermore, what is available to individuals in terms of financial products and options can rapidly change, meaning that previously acquired knowledge can be quickly out of date. As such, many individuals are not likely to ever attain critical levels of financial literacy (Beshears et al. 2011) and many individuals are essentially 'involuntary' investors, who are being asked to make important decisions in areas for which many have no experience or indeed interest in (Gallery et al. 2011).

A second factor concerns a lack of willingness to engage with such decisions. In the face of much choice and complexity, individuals can simply avoid an issue altogether, or simply revert to default options because that requires less effort. An example of avoidance is that many Australian baby boomers conduct little planning for retirement in addition to minimum SG contributions (Hunter et al. 2007). This avoidance of longer term plans for retirement needs is also reflected in other findings (Collins 2010; Iannicola and Parker 2010).

Also of interest are the actual behaviours and influences that emerge when individuals have to make financial decisions. The conventions of economic theory have been to assume that individuals make decisions to maximise their utility, based on a trade-off between risk and return. Yet from behavioural research it seems that individuals apply differing levels of importance to potential gains and losses, which themselves differ depending on their assessed likelihood (Bateman et al. 2010, Kahneman and Tversky 1979, Weber et al. 2011). Many other behavioural insights have been suggested since Kahneman and Tversky's (1979) groundbreaking paper in this field, including confirmation bias, and resorting to heuristics or simple rules of thumb when faced with complex choices.

\section{THE ROLE OF ADVICE}

It is apparent then that many individuals may not make good financial decisions if left to their own means (Mullainathan et al. 2012), particularly given the complexity that prevails today (RWA 2012). As such, many individuals seek help for various aspects of their financial affairs. The obvious point of call for assistance is professional advisers, but there are also a number of non-professional sources. These are discussed below.

\footnotetext{
${ }^{6}$ Major financial literacy surveys in Australia include a 2007 telephone survey of 7,500 Australians conducted on behalf of the Financial Literacy Foundation (FLF), and four surveys conducted on behalf of the ANZ (2002, 2005, 2008, 2011).
} 


\section{Non-professional sources of advice ${ }^{7}$}

People often utilise multiple non-professional sources of information to help with their financial decision-making (ANZ 2008). Those originating from social interactions can include family members, friends, work colleagues, and other peers.

Sources from more personal-oriented investigations can include media (such as the opinions of finance experts in newspapers, magazines, radio and television), publications directly from the finance industry, books, and government publications. Many sources such as the Product Disclosure Statements (PDS) of superannuation funds may be quite specific to a particular issue.

A further source which has grown in significance in recent years is the internet. Investors can now have much information as promptly as industry professionals, they can enter financial transactions independently of a professional if they choose to, and it can be done more cheaply than before (Smith 2009).

Although the range and variety of non-professional sources plays an important role and in some cases may be helpful, there are also risks. The first of these is that these sources may not in fact be providing appropriate advice. Indeed, if an individual has not been able to work out the advantages and disadvantages of certain decisions for themselves, relying on others who themselves may not have done so simply exacerbates the problem. In this sense the impact of peers may be as much a hindrance as a help.

Generational differences are also likely to be influential, with what was good advice twenty years not necessarily the case today. The use of the internet as a research tool can exacerbate these risks, where additional financial information can lead to individuals becoming over-confident, thinking they have greater knowledge than what they actually do have. This can lead to other apparent biases such as optimism and in particular, an illusion of control (Smith 2009).

A further risk relates to the uniqueness of each individual, with levels of family support, attitudes to risk, testamentary intent, belief(s) and attitudes towards retirement differing between individuals (McKee 2010). And, although some non-professional sources may provide specific guidance for specific issues, such advice is unlikely to be individualised for someone's particular circumstances (Iannicola and Parker 2011).

\section{Professional advice}

The Australian Financial Planning Association (FPA Australia) describes financial planning as 'developing strategies to help you manage your financial affairs and meet your life goals's ${ }^{\text {. This }}$ is essentially an interaction of goals (such as retirement) and beliefs (such as perceptions of money), with multiple functions required of a financial adviser in order to provide such a service. According to Kliplin (2010), an adviser should provide strategic advice ${ }^{9}$, tactical advice ${ }^{10}$, an

\footnotetext{
${ }^{7}$ References for this discussion include: FLF 2008, Gallery et al. 2011, Iannicola and Parker 2011, McAlexander and Scammon 1988, Mullainathan et al. 2012, Ntalianis and Wise 2011.

${ }^{8}$ http://www.fpa.asn.au/default.asp?action=article\&ID=22724, accessed 22 March 2013.

${ }_{9}$ Coaching and guiding individuals through various life changes.

${ }^{10}$ Expertise on insurance, investments and superannuation, as part of an individualised plan.
} 
implementation of decisions made, and then help keep individuals on track to achieve their financial goals. Similar functions are suggested by others ${ }^{11}$.

Financial planning is a relatively new profession, emerging from origins in life insurance sales, and some services offered by accountants, lawyers, and investment brokers (Cowen et al. 2011, Hunt et al. 2011, Santacruz 2011). From such relatively narrow specialties it continues to morph into a distinct service, though debate exists as to whether it is truly a 'profession' (Cowen et al. 2011, Murphy and Watts 2009).

A range of non-pecuniary benefits are associated with financial advice, and these are considered as important as any other benefits that might accrue to the customer (Collins 2010, Hunt et al. 2011, McKee 2010, RWA 2008). If an adviser operates as a financial coach to help the customer be aware and enabled to set specific goals and have an associated plan, then this can provide peace of mind (Kliplin 2010). If done realistically and comprehensively, this can provide the customer a degree of control as well as financial protection against unforeseen events, such as death or disability (RWA 2008). As such, those using financial advisers may be more engaged with their finances, allowing them to make informed decisions and willingly take responsibility for those decisions - in other words, empowering the client (Hunt et al. 2011, Kliplin 2010).

\section{The difficulty of assessing value}

Financial advice, however, is essentially a credence good with its quality being hard to assess (Bluethgen et al. 2008). This is also exacerbated by the complexity of the underlying issues that financial advice pertains to (FSA 2009). One major issue in discussing the quality of advice is the temporal nature of outcomes arising from that advice. The long term implications of financial decisions are significant and given the associated aspect of risk, this can mean that a focus on short term financial benefits can be inappropriate (Collins 2010). However, this itself opens up a number of issues.

Very poor advice and decisions can certainly lead to significant losses and poor outcomes in the short term, and these should not merely be waved away due to a fallback on 'it is the long term that matters'. And, it can also lead to spurious claims about the effectiveness of advice and quality of decisions, notably due to the cherry-picking of convenient data ${ }^{12}$. But, it is also the case that even when high quality advice may have been given, there may not necessarily be evidence in the short term of the quality of that advice. Whether it is the purchase of a product whose quality is not immediately obvious, or if advice is given to forego current consumption, it

\footnotetext{
${ }^{11}$ Financial planning occurs through "thorough collection and impartial analysis of information on the factual and affective dimensions of a person's or family's total financial situation; the identification of needs and the establishment of specific financial objectives; and the formulation, implementation, and continuous monitoring of a comprehensive financial plan to achieve them" (Johnson 1983, cited in McAlexander and Scammon 1988, p.185).

${ }^{12}$ For example, "it would not be unreasonable for many intelligent people... to believe there are very few financial professionals who lose. With so many possible measures of performance, it is difficult not to find one that looks good... (we were) presented with the record of a noted investment professional which showed below-average performance over the past 1,5 , and 10 years. Performance over the past 15 years, however, was above average. This was described as being noteworthy evidence that the professional was not interested in quick results but was investing for the long term” (Allen et al. 2000, p.429).
} 
can be difficult for the consumer to assess whether advice is sound within short time frames (Iannicola and Parker 2011) ${ }^{13}$.

The nature of financial outcomes also means that the results of advice are necessarily ones of probability, not certainty. In the context of institutional portfolios, Hedberg (1973) humorously points out that quality measured solely by a single result involves uncertainty "in a field where chance can, for a time, make a hero out of a fool, or a goat out of a conscientious analyst” (p.24). In other words, sometimes given advice may work out well, and sometimes it may not.

Another issue concerns the nature of 'product' versus 'strategic' advice, which is given significant attention by the Australian Securities and Investments Commission (ASIC 2014). Strategic advice considers broad requirements like the required level of retirement savings, sensible borrowing levels, investment risk appetite and appropriate amounts of insurance, separate to any recommendation for which product would be appropriate to implement the strategy. ASIC's view is that there is often an imbalance between the priority given to financial product advice, compared to strategic advice, as indicated in their significant review of retail life insurance advice (ASIC 2014). For many consumers, it is possible that there is not any obvious delineation between 'product' and 'strategic' advice.

Hence there are many difficulties when assessing the quality of financial advice, and it generally has to involve a qualitative judgement (Weatherhead 2009). As such, this means that the value of financial advice can be relatively intangible to some consumers ${ }^{14}$, and can be complicated further when determined by a consumer's own subjective judgement ${ }^{15}$.

\section{FOFA AND ‘BEST INTERESTS’ DUTY}

Following the collapse of multiple financial entities over 2006-2009 in Australia, an Inquiry was launched by the Parliamentary Joint Committee on Corporations and Financial Services (henceforth referred to as the PJCI). The findings of the PJCI were released in November 2009, with 11 key recommendations that touched on issues of regulation, training, education, professional standards, and adviser remuneration. Following these recommendations, a range of reforms (Future of Financial Advice (FOFA) reforms) for the financial planning industry were promulgated and then confirmed by the Australian government. Three key reforms included:

The banning of commissions to all but risk-only insurance products;

A requirement for advisers to get clients to opt-in (renew) their advice agreement every two years; and

A statutory fiduciary duty for financial advisers to act in the 'best interests' of their clients (Commonwealth of Australia 2011).

The response from the financial services industry was mixed, with concerns about some reforms being cumbersome, unnecessary, increasing the compliance burden, and having a bias

\footnotetext{
13 "Financial advice is not like hiring a plumber, in which the immediate and concrete benefit of the service is a fixed sink... the benefits of financial advice are delayed" (Iannicola and Parker 2010).

14 "If clients can touch it, feel it or see it, they know exactly what they're buying... but in professional advisory services, you never have the advantage of allowing the client to 'kick the tyres' the way sellers of products do" (Wijetllake 2012, p.24).

${ }^{15}$ As an additional analogy, with professions such as medicine there is good practice which nevertheless can result in undesirable outcomes, but there is also practice which can be professionally negligent. In financial affairs, it may not be straightforward for a disgruntled client to differentiate between the two.
} 
towards some segments of the industry (RiskInfo 2011). Although the Institute of Chartered Accountants in Australia agreed that the reforms will help remove conflicts of interest and improve the overall quality of financial advisory services, it also cautioned that the reforms had limitations (ICAA 2010). It called for a focus on the key drivers of quality in the context of financial advice, including higher education standards, the incorporation of practical and ethical components within such education, and importantly, "an overarching culture of operating in the public interest” (ICAA 2010).

\section{What is 'best-interests'?}

Having a 'best interests' duty is complicated by the combination of factors discussed to date. Where the quality of advice itself is hard to assess, the financial literacy of investors themselves is not especially cognizant of risk, and the financial landscape in Australia is complex, then knowing what 'best interests' is represented by is not a straightforward task.

One starting point is to consider guidance under recent regulatory settings, most obviously through the Corporations Act (2001) (Commonwealth of Australia 2001) and the Financial Services Reform Act (2001) (FSR) (Commonwealth of Australia 2005). Under the FSR, minimal regulatory intervention is seen as an appropriate approach to strike a balance between consumer protection and the capacity for markets to deliver innovation and efficiency. As such, risks exist for the customer because they can choose product(s) which are unsuitable for their circumstances, including those with features that they may know little about or are not in a position to manage effectively. Where personal financial advice has been given, the requirements and indeed obligations on the adviser boiled down to three key elements, that were expressed in the Corporations Act (2001), s945A(1). These were to:

- Understand the customer's relevant personal circumstances in relation to the advice being given;

- Give careful consideration to whether the advice is reasonable in all of the circumstances obtained above; and

-Ensure that the advice is appropriate to the customer, given those circumstances.

In other words, an adviser had to know their customer, know their product, and ensure that the product was appropriate for that customer. Such advice had to be 'reasonable' and appropriate, and it provided an obligation on the adviser to specify advice specific for the particular customer. Nevertheless, 'appropriate' is not necessarily synonymous with 'best interests', with the latter intended to be a stronger requirement. Indeed, 'best interests' is described as requiring a financial planner to act in the best interest of the client in relation to the advice (FPA 2013), rather than the less stringent test of reasonableness that previously applied.

The original FOFA reforms incorporated into the Corporations Act a series of steps that when followed, intended to show that the best interests test had been met (Corporations Act 2001 s961B(2)(a)-(g)). Subsequent reforms to the provisions by the Coalition Government removed s961B(2)(g) from the Corporations Act, which was a broader clause focusing less on process than the previous steps. There has been considerable debate amongst industry groups, practitioners and the legal community as to whether the removal of s961B(2)(g) results in a lower level of protection to consumers. Some groups argue there is no practical impact (Holley 2014, Stewart 2014), whereas others describe its removal as leaving only a checklist-based process that weakens consumer protections (ISA 2014). Indeed, ISA (2014) highlights that 
although the remaining subsections (a) to (f) are important, they "do not even mention a client's best interests", and “fall well short of requiring advice in the client's best interests” (p.21).

\section{METHODOLOGICAL OVERVIEW}

It can be difficult then to establish what is truly meant and ultimately intended by 'best interests' What we offer is to highlight features of advice arising from a specific case study (Storm Financial), which indicates what is not meant by 'best interests'. In this manner, we suggest that there are at least bounds on what 'best interests' could be seen to be, which serves as a signpost as to the expectation of financial advice given under the FOFA reforms.

\section{Storm Financial}

Queensland-based Storm Financial was a financial advice company which collapsed suddenly in late 2008 / early 2009. The losses for its 14,000 investors were significant, with total reportedly in the region of $\$ 3$ billion (St. John 2011) ${ }^{16}$. Storm's investment model required investors to source funds from superannuation, the sale of personal assets, other savings, and new mortgages against the home. Against the accumulation of all of these an additional margin loan was often also taken, with this strategy to both mortgage the home and take out an additional margin loan referred to as ‘double gearing' or 'leverage on leverage' (Ferris 2011, Smith 2009). The margin loans were usually provided by Macquarie Bank or subsidiaries of the Commonwealth Banks of Australia (CBA) (Barry 2009, Ferris 2011). All subsequent funds arising were then available for investment into an equity-based index fund. Over time investors were encouraged to increase the absolute size of their investment, in line with growth in the equity investment and house values (Barry 2009). Investors were mainly retirees, or those close to retirement. As such and given the leverage involved, many investors lost not only their investments but also their homes and entire life savings, and many were also left with large debts in the form of home mortgages and/or loans to providers of margin loans.

\section{Data and methodological overview}

We make use of the significant qualitative data that is available concerning the collapse of Storm, as an informative case study. As part of the PJCI there were numerous submissions, public hearings and public commentary made on the circumstances and lessons of the collapse. We also sourced 13 individual participants (a participant is either an individual or a couple) who were Storm investors, and 2 ex-Storm advisers, for personal interviews which took place over 2011 - 2012. Through presentations and some publicity amongst other investors, we also received additional correspondence throughout this research, providing another insightful data source. A summary of the data used as part of this research is given below.

\footnotetext{
${ }^{16}$ The exact figure is disputed, with ASIC (2012) claiming that "the total loss suffered by all investors who borrowed monies from financiers to invest through Storm to be approximately $\$ 832$ million...ASIC does not know of any reliable source for the $\$ 3$ billion loss figure”.
} 
Table 1: Summary of data sources

\begin{tabular}{|c|c|c|}
\hline Source of Data $^{17}$ & Description & Volume of data \\
\hline $\begin{array}{l}\text { Submissions to } \\
\text { PJCI }\end{array}$ & $\begin{array}{l}\text { Anyone with an interest in the } \\
\text { purposes of the PJCI could make } \\
\text { a public submission. }\end{array}$ & $\begin{array}{l}398 \text { publicly available submissions, } \\
\text { constituting } 2,879 \text { pages of written } \\
\text { material. }\end{array}$ \\
\hline $\begin{array}{l}\text { Public hearings of } \\
\text { PJCI }\end{array}$ & $\begin{array}{l}\text { Public hearings were held as part } \\
\text { of the PJCI throughout Australia } \\
\text { in } 2009 .\end{array}$ & $\begin{array}{l}\text { Nine public hearings, with } 40 \text { distinct } \\
\text { parties (106 individuals) appearing } \\
\text { and giving testimony, giving rise to } \\
823 \text { pages of written transcripts. }\end{array}$ \\
\hline Interviews & $\begin{array}{l}15 \text { interviews with ex-Storm } \\
\text { investors and ex-Storm advisers } \\
\text { took place over } 2011-12 \text {. }\end{array}$ & $\begin{array}{l}21 \text { hours of recorded conversation, } \\
\text { and } 402 \text { pages of interview } \\
\text { transcripts. }\end{array}$ \\
\hline Observations & $\begin{array}{l}\text { Observations were taken at } \\
\text { interviews; and observations of } \\
\text { many commentators are available } \\
\text { through media and reports. }\end{array}$ & N/A \\
\hline $\begin{array}{c}\text { Other } \\
\text { correspondence }\end{array}$ & $\begin{array}{l}\text { Various feedback was } \\
\text { received from other parties, } \\
\text { arising from presentations and } \\
\text { earlier production and distribution } \\
\text { of } 2 \text { industry journals }{ }^{18} \text {. }\end{array}$ & $\begin{array}{l}\text { Written comments from eight } \\
\text { financial advisers and seven } \\
\text { additional ex-Storm investors; } \\
\text { numerous verbal feedback and } \\
\text { insights. }\end{array}$ \\
\hline
\end{tabular}

Deducing key findings from such a large quantity of qualitative data is not straightforward, and demonstrating the validity and credibility of these findings is also challenging. The approach adopted to draw out key findings was based on elements of grounded theory and narrative analysis, and ensuring that these findings represent a reasonable series of insights into what is resident within the underlying data was enhanced through the use of several procedures considered to be reasonable in the qualitative research literature. This included the use of participant quotations, peer review, purposeful sampling, thick description, member checking, triangulation, and mechanically recorded data. To place this in context, engaging in at least two out of eight named key procedures is considered reasonable ${ }^{19}$. A full discussion of strengths and weaknesses of such qualitative approaches, the detail of the analytical steps taken, and the rationale for the validation procedures adopted is given in Bruhn (2013).

17 Public Submissions and transcripts of public hearings can be sourced from http://www.aph.gov.au/Parliamentary_Business/Committees/Joint/Corporations_and_Financial_Services/Completed inquiries/2008-10/fps/index

${ }^{\overline{18}}$ Presentations have included those to: ANU colleagues (2011, 2013); a US Society of Actuaries conference (2011); an academic, actuarial and regulatory audience at the University of Auckland (2012); MLC financial advisers (2014); the Actuaries Institute Financial Services Forum (2014); and the ACT branch of the Statistical Society of Australian (2014). The two industry papers produced early in the research were: 'Surprises from Storm' (Journal of Financial Advice August 2012), and 'Aftermath of a Storm’ (The Australian Journal of Financial Planning March 2013).

${ }^{19}$ These are (a) prolonged engagement and persistent observation, (b) triangulation, (c) peer review or debriefing, (d) negative case analysis, (e) clarifying researcher bias, (f) member checks, (g) thick description, and (h) external audits (Creswell 1998, cited in Anfara et al. 2002, p.30). 


\section{ESTABLISHING BOUNDS ON 'BEST INTERESTS’}

In terms of submissions made to the PJCI, 14 out of 43 public submissions from financial planning businesses and seven out of 21 financial service organisations / institutes / associations documented some concern about the overall strategy offered by Storm. The major areas commented on were risk levels and tolerance, assumptions underlying the investment strategy, the use of the one-size-fits all approach, the use of debt, and the self-selection aspect of investors joining Storm. We also consider that 'concentration risk' is highly relevant. We give an overview of the specific concerns expressed about Storm's strategy, using a selection of views from the available data, to inform the debate about what is represented by a 'best interests' duty ${ }^{20}$.

\section{Risk levels and tolerance}

Two aspects of risk were highlighted. The first of these was that the overall level of risk was inappropriate and too high given the likely tolerance levels of the target market of more mature investors. The Institute of Actuaries of Australia bluntly asserted that the strategy adopted, 'on any objective test, is inappropriate and involves an excessive level of risk, given their circumstances' (submission 319). Various financial advisers also offered a critique, one stating that the advice was 'grossly irresponsible' due to the predominance of investors near 'the end of the wealth accumulation stage of their lives' having 'no prior exposure to the stock market or indeed leveraging' (submission 332). In other words, and according to another financial adviser company, 'they simply took no account of the clients' financial risk tolerance' (submission 324).

A second aspect of risk concerned the communication of that risk to investors. Storm offered all prospective investors a series of education seminars, to equip investors with a good understanding of all aspects of the investment (Dias 2009). Attendance was a general requirement prior to making a decision to proceed, and the process could take up to six months. Ferris (2011) states that these educational seminars were lengthy and had supporting written material, including 100-page long statements of advice ${ }^{21}$ which, unfortunately, many investors 'did not understand'. AXA's submission (385) to the PJCI also commented on this issue:

It seems unlikely that so many people would have mortgaged the family home, their only asset, if they had understood that there was a significant risk that they could lose it as a result of a decline in investment markets.

\section{Assumptions underlying the investment strategy}

Many observers commented that Storm's advice model was predicated on a poor understanding of market fundamentals. One financial company stated that the overall failure was due to the assumption of 'the Stock Market continuing to "bull run"' (submission 330), and fairly blunt

\footnotetext{
${ }^{20}$ It is noted that Storm's founder, Emmanuel Cassimatis, gives a defence of many aspects of Storm's strategy to PJCI members in the Brisbane public hearing of 3 September 2009. An ex-Storm adviser presents a similar case in the Cairns public hearing of 1 September 2009, with his overall view that the key issue is not one of Storm's strategy but rather the action(s) of the behaviour of the CBA, a key credit provider associated with Storm's advice model.

${ }^{21}$ However, although some risks were given in writing, these were "apparently undermined by verbal assurances from the trusted Storm advisers. The Storm investors were repeatedly assured that their homes were not at risk" (Ferris 2011).
} 
assessments were also provided by other financial planners (for example, submission 168). Another financial adviser observed that it was the combination of underlying beliefs about the market, with other risk factors within the Storm model that represented the real crux of the risk at play:

No planner worth their salt should claim to be able to pick the timing, or even frequency of share market volatility. Where a client presents though at close to the end of their working career, without other significant financial resources, there are enough knowns to tell a good planner that a gearing (and double gearing on top!) strategy is not appropriate. (email from financial adviser, June 2013)

It is opportune here to highlight one aspect of the basis underlying the investment strategy, as put forward by Storm. We refer to the following excerpt:

Senator McLucas: What did the (education sessions offered by Storm) cover?

Mr Cassimatis: It covered technical aspects of finance, the psychology of investing, accounting principles, financial principles and risk. Specifically, because our space was leverage, it gave explanations as to how wealth can be enhanced significantly using leverage, and it also gave quite horrific examples of how equity gets destroyed when markets are negative, but then in the end it is the averages that count. (Brisbane public hearing of 3 September 2009, p.22)

It may be that the reference above to the primacy of 'average returns' is meant to highlight that such strategies require a long term rather than short term horizon and as such it is long term trends that are more important than shorter term fluctuations. Other than the risks involved with gearing, with such an inference we have little issue. If however there is a belief that a long term average returns are what count most of all, then this misses the key point of risk.

A simplified example makes this clear. Suppose a strategy starts off with $\$ 100$ of assets and $\$ \mathrm{x}$ of liabilities by way of margin loan (to give net assets of $\$(100-\mathrm{x})$ and a loan to value ratio (LVR) of $\mathrm{x} \%$ ), and that at the end of each year the overall position is rebalanced, through extra loans for further investment, to maintain that LVR of $\mathrm{x} \%$. Then, consider two scenarios:

(1) returns are $+20 \%$ per annum for 9 years and then $-50 \%$ in year 10 ;

(2) returns are $+9.94 \%$ for each of 10 years

Both cases have the same 10-year average geometric return. Yet, the relative net positions after 10 years vary enormously under various LVRs, as per the following:

Table 2: Outcomes of investment scenarios with margin lending

\begin{tabular}{|c|c|r|r|}
\hline \multirow{2}{*}{ LVR (\%) } & \multicolumn{2}{|c|}{$\begin{array}{c}\text { Net position (assets minus } \\
\text { liabilities) after 10 years under: }\end{array}$} & $\begin{array}{c}\text { Difference between outcomes, } \\
\text { expressed as a \% of the net assets } \\
\text { held at t }=\mathbf{0}\end{array}$ \\
\cline { 2 - 3 } & Scenario (1) & Scenario (2) & \begin{tabular}{c} 
(1) \\
\hline $40 \%$
\end{tabular} \\
\hline$\$ 133$ & $+\$ 278$ & $614 \%$ \\
\hline $50 \%$ & $\$ 0$ & $+\$ 307$ & $1,880 \%$ \\
\hline $60 \%$ & $-\$ 384$ & $+\$ 368$ & $8,367 \%$ \\
\hline $70 \%$ & $-\$ 1,985$ & $+\$ 525$ & $82,450 \%$ \\
\hline $80 \%$ & $-\$ 15,360$ & $+\$ 1,130$ & \\
\hline
\end{tabular}


Notably, to focus on the differences in LVRs in terms of investment outcomes, this analysis assumes an interest rate of $0 \%$ on the margin loan itself. With an interest rate of approximately $10 \%$ on the margin loan, then the higher the LVR, the more pronounced also this interest burden would be. Clearly, any geared strategy can be under severe stress unless it is very conservative, and merely an average return being reasonable says nothing about the underlying risk involved. Yet, the ten-year annual geometric return of $+9.94 \%$ for both scenarios is attractive and in any appeal to a long term horizon, the associated risks may not be understood, or may be underplayed.

\section{One size fits all}

Another criticism was the use of a 'one-size-fits-all' strategy whereby the same model of advice and product was given to investors, regardless of their personal circumstances (Barry 2009, Ferris 2011, Smith 2009). The inappropriateness of this was not necessarily the product itself in isolation, but the matching of the product with those for whom it was unsuitable. For example, those with low incomes would be at the mercy of adverse interest rate movements on the loans, and particularly for those who had ceased work, this risk was exacerbated (Smith 2009). Furthermore, despite a long term investment horizon being more appropriate for Storm's model of high levels of debt in conjunction with large up front commissions, the target market was predominantly retirees or those close to it. The additional high levels of gearing on that debt make for a risky overall concoction, yet such highly geared strategies were recommended to those who could ill-afford it (Ferris 2011). And, even if all the above criteria were satisfied by a particular investor, that investor should also have a high level of knowledge of the intricacies and detail of the overall strategy. Yet this too was unlikely in many cases, particularly with respect to the risks posed by the leveraging strategy (Smith 2009).

The fact that Storm's founders and ex-Storm advisers also suffered from their own personal losses strengthened the criticism in some quarters of the inappropriateness of the advice $^{22}$. The suggestion and adoption of a certain level of risk tolerance and appetite by a potential investor is not made more appropriate or credible, simply because the adviser has adopted this for themselves ${ }^{23}$. In this sense, it is an ironic twist that a product can be made more appealing via an adviser's personal assurances, when on closer inspection this is misleading in the financial context where investors are not homogeneous agents. In fact, doing so does not heed relevant legal and professional guidance to 'know the client' and ensure the tailoring of advice specifically to that client.

The issue of advice not being suitable for individual circumstances was widely commented on - for example, the CEO of IFSA ${ }^{24}$ (Canberra public hearing of 28 August 2009, p.53); a financial consulting group (Melbourne public hearing of 26 August 2009, p.96); and submissions

\footnotetext{
22 "The founders of Storm... along with most advisers and key staff, are all in the same boat as some of our clients. We have all followed the same investment and lending within our portfolios, have our homes mortgaged and have suffered the declines in the markets due to the financial crisis... while this is no consolation, we are sure it proves we have not acted differently for ourselves. Being in the front line of course makes us the first casualties" (Storm founder Emmanuel Cassimatis, cited in Raggart 2009).

${ }^{23}$ Indeed, "whilst it's not unreasonable for the baker to say that he eats his own bread it is clearly inconsistent for a financial planner to give all his clients a similar and very risky strategy even if it is the same one he has adopted for himself" (FinaMetrica 2009).

${ }^{24}$ The Investment and Financial Services Association.
} 
154, 293 and 385 from consulting group AEC, a financial planning company, and AXA, respectively. Another financial planning business expressed their concern as follows:

They simply offered one solution, which was for clients to borrow heavily against their homes and to use this to leverage further into margin loan and invest $100 \%$ into Australian shares... (they) had a square hole and jammed people into it no matter their shape and size... Storm Financial had clients on the Aged Pension and minimal other income signing up to borrow \$1 million. Irrespective of market conditions, how is that appropriate financial advice? (submission 178)

An ex-Storm adviser commented succinctly in an interview their reflection on not having a 'solution for each individual person', in that 'you don't have one solution fits all, that's bulls---'. Another ex-adviser also commented on this aspect of Storm’s approach:

The one size fits all...that was a problem because they were lumping retirees in with the general public and that's where most of the problems have emerged... the one size fits all obviously, clearly doesn't work. It doesn’t work because the guy in Cooktown requiring $\$ 90$ a week and being genuinely happy, needs a plan very different to the guy that wants two planes. [interview with exStorm adviser]

\section{Self-selection}

Storm's approach to let potential investors 'opt-in' to their commoditised, rather than individualised advice offering (with advice effectively 'packaged' as a part of the product), was also commented on. Indeed, this process of 'self-selection' into Storm's model was the mechanism for the 'one-size-fits-all' issue arising, but there were subtleties to it that deserve mention.

The FPA's deputy CEO described the practice of self-selection where 'clients were asked to qualify themselves as being suitable for the strategy' as 'very uncommon'. Clients were effectively asked by Storm, 'if you want to achieve these goals and these outcomes then this is the sort of client you need to be... (are you) that client?' In other words, 'clients were invited to qualify themselves into the relationship’, which Senator Mason of the PJCI bluntly assessed as a breach of professional expertise: 'This is a professionalised industry. You cannot let people prequalify and determine what they think they are' (Canberra public hearing of 28 August 2009, p.30). The Institute of Chartered Accountants in Australia also picked up critically on this issue, with their view that 'the responsibility still goes back to the adviser and the advice being provided’. Further, they added that:

The client may self-select and say, 'I am interested in going forward with this,' but in the current environment it is still the responsibility of the adviser to provide appropriate advice... part of the role of the adviser is to say, 'This is not appropriate for you.' ...if a person is retired, is paying off their home and is elderly, gearing is not an appropriate option, and if the client is saying, 'This sounds great; I want to head down that track,' a professional needs to take a position and say: 'No, it is not appropriate for you. There are other solutions.' (Sydney public hearing of 4 September 2009, p.15). 


\section{The use of debt}

The use of margin lending is one of the more debated issues within the overall strategy adopted by Storm. Certainly there was little to support its utility to the extent, market and manner adopted by Storm, but nevertheless it was not necessarily considered an inappropriate strategy per se. For example, the CEO of MLC Limited stated that margin lending can be 'an appropriate product' (Melbourne public hearing of 26 August 2009, p.14), a financial adviser stated in email correspondence that 'gearing is a legitimate strategy for the right type of client' (April 2013), and IFSA stated their view that 'a high level of leverage is, in and of itself, (not) inappropriate for retail investors’ (submission 317).

Furthermore and despite their poor experiences, some interviewed investors still held it to be a workable approach in some circumstances, albeit with different parameters to that which they had with Storm:

Husband: We've got a friend here who is one of the richest guys (locally) and he says, "Quite frankly, it sounds like a pretty good scheme to me except you were very unlucky for it to have hit the global financial crisis."

Wife: And that it was too highly geared.... the model itself would have worked if it had been geared at about 25 per cent. (interview with Storm investors)

Another interviewed ex-investor has actually gone into a gearing strategy again, but with more conservative parameters. An ex-Storm adviser also continues to attest to the value inherent with gearing strategies, but on reflection with more regard being paid to the risks involved:

I used the model well before I got involved with Storm and it works... the issue here was the borrowing... it was just far too much... the model unquestionably works if the debt levels were set at appropriate levels much more moderate than they were... the level of debt to pensioners, to people who weren't working, was crazy... you either had to be employed, you had to have a very good understanding of where we were going... on reflection, gearing for retirees is dumb, right? ... Now with the benefit of hindsight, it doesn't work for retirees at the level of debt that was loaded. (interview with ex-Storm adviser)

The aspect of risk is therefore a key concern of such arrangements, reiterating earlier comments. Despite stating that leverage can be appropriate, IFSA also cautioned that important and additional risks are also involved (submission 317), and the CEO of the Association of Financial Advisers stated that any margin lending product should be "handled with care", and any double-geared margin lending product should be "handled with serious care' (Sydney public hearing of 4 September 2009, p.42). The CEO of Macquarie Bank also testified that their advice to customers includes a statement of the additional and significant risks involved, and management thereof:

'Be conservative in the amount that you borrow, always borrow within your capacity so you can accommodate any interest-rate rises, check the lending ratios before implementing the plan, diversify your investments, reinvest dividends to reduce your loan as a proportion of your total portfolio, make interest payments regularly, ensure that you have stable cash flow to meet interest payment obligations, monitor your investments closely, and invest for the long term'. (Canberra public hearing of 28 October 2009, p.15) 


\section{Concentration Risk}

A major shortfall of Storm's model that many investors would have been oblivious to is what we term 'concentration risk'. Some interviewees made an analogous comparison of the strategy to borrow against both the home and against total investment assets via a margin loan, with that of taking out a mortgage for home purchase. Whilst both are similar in that money has been borrowed, there is little further common ground. The ability to service a mortgage depends on the borrower's income (and if investment earnings were available, they would be independent of that income). In contrast, the ability to service both a mortgage and investment loan under Storm's model predominantly depends on investments held. However, when investment values fall and thereby raise the LVR, income from those investments is also likely to fall, compromising the ability to service the loans. Depending on the size of money put aside for a cash 'dam' (as labelled by Storm) to provide for living and interest expenses, a point will be breached when servicing the loans themselves is under pressure, adding further pressure on the LVRs. In other words, when it rains (investment markets drop), it doesn't just pour (LVRs increase due to decreasing investment values), it actually turns torrential (loan servicing runs the risk of being compromised, on both mortgage and investment loans). This does not make such a strategy inappropriate for all people, but in all probability it was inappropriate for the majority of Storm's investors. One financial planner made this point:

When you borrow to invest you should have cash flow to support that. Essentially, this model borrowed the cash flow, and that is where everything started to tumble down. If I am doing margin lending and, indeed, if I am doing double gearing... I have got to have the cash flow to support it. The failing here was about borrowing to pay for it as well as to build that wealth to pay for their retirement lifestyle. (Cairns public hearing of 1 September 2009, p.95)

Overall, where a defence of the overall strategy has been given (such as in the public hearings mentioned in footnote $\{20\}$, as well as in submission 281), we note further that: (1), those who actually paid out margin loans suffered major losses as well; and (2), the concentration risk above would trump most reasonable protective measures in a big enough market fall (short of having costly cash 'dams' and ratios set at levels so as to render the leveraging strategy pointless). Furthermore, although it is clear that the GFC was the catalyst that led to Storm's collapse, this was not the basis for the overall criticism of Storm's strategy. As the CEO of IFSA attested:

The requirement for appropriate advice is significant. We believe that the activities of Storm with respect to some of their clients were not appropriate. They did not give appropriate advice. And that act existed well before the crisis. (Canberra public hearing of 28 August 2009, p.59)

\section{CONCLUSION}

Recent reforms have introduced the concept of a 'best interests' duty in respect of professional financial advice. The need for quality finance is significant, and as such this reform seems timely. Yet, the value of financial advice is very hard to assess, which generates a significant challenge in defining and applying what is meant by 'best interests', for the benefit of consumers, regulators, and indeed advisers themselves. 
By referring to the collapse of Storm Financial as a case study, we offer some further discussion on what might be described by a best-interests duty. Some major lessons from Storm's collapse suggest that this duty could, depending on the specific situation, give attention to the following key aspects:
Risk levels and tolerance of the individual customer. These cannot be merely assumed, especially if risk is not presented in a way which is meaningful to the customer. Neither can it be assumed that the customer applies similar levels of importance to potential gains and losses; Clarity and communication about the underlying assumptions made regarding the investment strategy, particularly regarding the belief of the adviser as to the nature and features of market returns and behaviour; Advice must be individualised to a customer's explicit beliefs and expectations about risk, and their own goals. Blanket statements, generalised assumptions, and a lack of some defined goal are likely to render a best-interests duty intractable; The use of debt and additional borrowing, in any shape or form, should be replete with warnings about its use in the context of an individual's own risk appetite and goals;
The advice process should allow, and perhaps even promote, the right of the customer to seek alternative advice for either holistic or piecemeal aspects of the advice being offered;
The choice to proceed with a certain course of action may be the right of a customer, but this does not obviate the requirement for an adviser to exercise judgement and caution if they believe this is not the best course of action to take, given the risk appetite and goals of the customer;
Particular risks reside within certain strategies that may not be obvious to adviser nor customer, such as 'concentration risk'. It is possible that a best-interests duty could require a mandated element of professional peer review in terms of process, or specific recommendations being made.

We do not believe that there is any 'silver bullet' to specify what is meant by a bestinterests duty. Advice itself necessarily involves judgement and it delivers outcomes which are probabilistic in nature. However, the key aspects arising from the case study of Storm are that personalised advice which explicitly accounts for a customer's goals and risk appetite is essential, as is the relationship between goals and risk, and as is the clear and unambiguous presentation of risk in terms that is meaningful to whom it relates.

\section{References}

Allen, DE, McGoun, EG \& Kester, GW 2000, 'A sociological explanation of financial market growth’, International Review of Financial Analysis, vol. 9, issue 4, Winter 2000, pp. 421432. http://dx.doi.org/10.1016/S1057-5219(00)00040-5

Anfara, VA, Brown, KM \& Mangione, TL 2002, 'Qualitative analysis on stage: Making the research process more public’, Educational Researcher, 31(7), pp. 28-38. http://dx.doi.org/10.3102/0013189X031007028 
ANZ (Australian and New Zealand Banking Group) 2002, ‘ANZ Survey of Adult Financial Literacy in Australia - Final Report', Roy Morgan Research. : 2005, 'ANZ Survey of Adult Financial Literacy in Australia', AC Nielson Research. : 2008, 'ANZ Survey of Adult Financial Literacy in Australia', The Social Research Centre.

: 2011, 'ANZ Survey of Adult Financial Literacy in Australia', ANZ and Roy Morgan Research.

ASIC (Australian Securities \& Investments Commission) 2003, 'Financial literacy in schools', Consultation paper 45 (June 2003), http://www.asic.gov.au/asic/pdflib.nsf/LookupByFileName/FinLit_schools_DP.pdf/\$file/Fi nLit_schools_DP.pdf. : 2012, 'ASIC and CBA Storm Financial settlement', http://www.asic.gov.au/asic/pdflib.nsf/LookupByFileName/ASIC-and-CBA-Stormfinancial-settlement-19-November-2012.pdf/\$file/ASIC-and-CBA-Storm-financialsettlement-19-November-2012.pdf, accessed 22 November 2012. : 2014, 'Review of retail life insurance advice', Report 413 (October 2014), https://dv8nx270cl59a.cloudfront.net/media/2012616/rep413-published-9-october2014.pdf.

Barry, D 2009, 'Ripoll Committee report tells a tale of Storm Financial greed', Woolly Days Blog, http://nebuchadnezzarwoollyd.blogspot.com.au/2009/11/ripoll-committee-reporttells-tale-of.html, accessed 20 October 2010.

Bateman, H, Louviere, J, Satchell, S, Islam, T \& Thorp, S 2010, 'Retirement Investor Risk Tolerance in Tranquil and Crisis Periods: Experimental Survey Evidence’, UNSW Australian School of Business Research Paper No. 2010ACTL10 (25 August 2010), http://ssrn.com/abstract=1665948.

Bateman, H, Eckert, C, Geweke, J, Louviere, J, Satchell, S \&Thorp, S 2011a, 'Financial competence, risk presentation and retirement portfolio preferences', Australian School of Business Research Paper No. 2011ACTL03, The University of New South Wales.

Bateman, H, Eckert, C, Geweke, J, Louviere, J, Satchell, S \& Thorp, S 2011b, 'Financial competence and expectations formation: evidence from Australia', Australian School of Business Research Paper No. 2011ACTL07, The University of New South Wales.

Beshears, J, Choi, JJ, Laibson, D \& Madrian, BC 2011, 'Behavioral economics perspectives on public sector pension plans', Journal of Pension Economics and Finance, Vol 10, Issue 2, April 2011, pp. 315-336. http://dx.doi.org/10.1017/S1474747211000114

Bluethgen, R, Meyer, S \& Hackethal, A 2008, 'High-Quality Financial Advice Wanted!', 20 February 2008, http://ssrn.com/abstract=1102445.

Bodie, Z, Treussard, J \& Willen, P 2008, 'The Theory of Optimal Life-Cycle Saving and Investing', Session 1 in Z. Bodie, Z., D.W. McLeavey \& L.B. Siegel (eds.), The Future of Life-Cycle Saving and Investing, $2^{\text {nd }}$ edition (February 2008), Research Foundation Publications, CFA Institute, pp. 19-37.

Bruhn A 2013, 'What happens when it all goes wrong - A study into the impacts of personal financial shocks'. Thesis for the degree of Doctor of Philosophy of The Australian National University, Canberra: December 2013.

Campbell, J 2006, 'Household Finance', Journal of Finance, vol. 61, issue 4, pp. 1553-1604. http://dx.doi.org/10.1111/j.1540-6261.2006.00883.x 
Chardon, T 2011, 'Weathering the Storm: Tax as a Component of Financial Capability', Australasian Accounting Business and Finance Journal, 5(2), pp. 53-68.

Collins, JM 2010, 'A Review of Financial Advice Models and the Take-Up of Financial Advice', Center for Financial Security, University of Wisconsin-Madison Working Paper WP 10-5, September 2010.

Commonwealth of Australia 2001, 'Corporations Act 2001', ComLaw, http://www.comlaw.gov.au/Series/C2004A00818.

: 2005, 'Financial Services Reform Act 2001', ComLaw,

http://www.comlaw.gov.au/Details/C2005C00498. : 2011, 'Future of Financial Advice Information Pack', 28 April 2011, http://futureofadvice.treasury.gov.au/content/Content.aspx?doc=reforms.htm.

Cowen, J, Blair, W \& Taylor, S 2011, 'The Use of Scaffolding in the Financial Planning Classroom: An Australian Case Study’, Australasian Accounting Business and Finance Journal, 5(3), 2011, pp. 3-16.

Dias, B 2009, 'Jelich breaks his silence on Storm', Redcliffe and Bayside Herald 18 February 2009, http://redcliffe-and-bayside-herald.whereilive.com.au/news/story/jelich-breaks-hissilence-on-storm/, accessed 8 November 2011.

Fear, J 2008, 'Choice Overload, Australians coping with financial decisions', The Australia Institute, May 2008.

Ferris, S 2011, 'Unlocking the Equity in Your Home’, Actuary Australia, July 2011, The Institute of Actuaries of Australia, pp. 16-19.

FinaMetrica 2009, 'Financial Planning at the Crossroads?’, February 2009, http://www.riskprofiling.com/Downloads/PR_CR.pdf, accessed 6 September 2011.

FLF (Financial Literacy Foundation) 2007, 'Financial Literacy: Australians Understanding Money', Commonwealth of Australia.

: 2008, 'Financial Literacy: Women Understanding Money’, Commonwealth of Australia.

FPA (Financial Planning Association of Australia) 2013, 'Best Interests Duty Easy Reference Guide’, Financial Planning Association of Australia.

FSA (Financial Services Authority) 2009, 'Describing advice services and adviser charging', report for the Financial Services Authority by IFF Research, June 2009, http://www.fsa.gov.uk/Pages/Library/research/Consumer/index.shtml.

Gallery, N, Newton, C \& Palm, C 2011, 'Framework for Assessing Financial Literacy and Superannuation Investment Choice Decisions’, Australasian Accounting Business and Finance Journal, 5(2), pp. 3-22.

Hedberg, RD 1973, 'Let's Regulate Investment Advice’, Financial Analysts Journal, 29(3) (May-June 1973), pp. 24-26 \& 102-103, CFA Institute.

Holley, G 2014, 'FOFA changes to best interests: A storm in a tea cup?', Holley Nethercote Commercial \& Financial Services Lawyers,

http://www.hnlaw.com.au/site/DefaultSite/filesystem/documents/FOFA_changes_to_best_i nterests_a_storm_in_a_tea_cup.pdf.

Hunt, K, Brimble, M \& Freudenberg, B 2011, 'Determinants of Client-Professional Relationship Quality in the Financial Planning Setting', Australasian Accounting Business and Finance Journal, 5(2), 2011, pp. 69-99.

Hunter, W, Wang, W \& Worsley, A 2007, 'Retirement planning and expectations of Australian babyboomers: are they ready to retire?', Annals of the New York Academy of Sciences, 1114(1) October 2007, pp. 267-278. http://dx.doi.org/10.1196/annals.1396.024 
Iannicola, D \& Parker, R 2010, 'Barriers to Financial Advice For Non-Affluent Consumers', sponsored by the Society of Actuaries, prepared by The Financial Literacy Group, September 2010.

: 2011, 'Why They're Not Listening', The Actuary, Society of Actuaries, February/March 2011, Vol. 8, Issue 1, pp. 26-31.

ICAA (Institute of Chartered Accountants in Australia) 2010, 'Financial advice reforms paint optimistic future for industry’, Media Release of 26 April 2010, http://www.charteredaccountants.com.au/News-Media/Media-centre/2010/Financialadvice-reforms-paint-optimistic-future-for-industry.aspx.

ISA (Industry Super Australia) 2014, 'Submission to the Senate Economics Legislation Committee: Corporations Amendment (Streamlining of Future of Financial Advice) Bill 2014'.

Kahneman, D \& Tversky, A 1979, 'Prospect Theory: An Analysis of Decision Under Risk', Econometrica, Vol. 47, No. 1., pp. 263-291. http://dx.doi.org/10.2307/1914185

Kliplin, R 2010, 'Back to Basics - Why People with Financial Advisers are Happier, Richer and more Purposeful', The Australian Journal of Financial Planning, Vol.5, No. 2, pp. 21-33.

Lusardi, A \& Mitchell, OS 2011, 'Financial literacy around the world: an overview', Journal of Pension Economics and Finance, Vol. 10, Issue 4, October 2011, pp. 497-508. http://dx.doi.org/10.1017/S1474747211000448

MacDonald, BJ, Jones, B, Morrison, RJ, Brown, RL \& Hardy, M 2011, 'Research and Reality A Literature Review on Drawing Down Retirement Savings', Society of Actuaries, http://www.soa.org/research/research-projects/pension/default.aspx.

McAlexander, JH \& Scammon, DL 1988, 'Are Disclosures Sufficient? A Micro Analysis of Impact in the Financial Services Market’, Journal of Public Policy \& Marketing, Vol. 7, Special Issue on the FTC (1988), pp. 185-202.

McKee, A 2010, 'Role of Advisers within the Financial Services Market - Lynchpin or Leech?', presented to the Institute of Actuaries of Australia, 5th Financial Services Forum, 13-14 May 2010, Sydney.

Mullainathan, S, Noeth, M \& Schoar, A 2012, 'The Market For Financial Advice: An Audit Study’, NBER Working Paper No. 17929, March 2012.

Murphy, B \& Watts, T 2009, 'Financial Planning in Australia: Industry or Profession?', 14th Finsia-MCFS Banking \& Finance Conference (pp. 1-24), Melbourne, Australia: Melbourne Centre for Financial Studies.

Ntalianis, M \& Wise, V 2011, 'The Role of Financial Education in Retirement Planning', Australasian Accounting Business and Finance Journal, 5(2), 2011, pp. 23-37.

Raggart, T 2009, 'Storm Financial bosses break their silence', Townsville Bulletin 7 January 2009, http://www.townsvillebulletin.com.au/article/2009/01/07/31725_hpnews.html, accessed 3 November 2012.

RiskInfo 2011, 'Mixed Industry Response to FoFA Legislation', 31 August 2011, http://riskinfo.com.au/news/2011/08/31/mixed-industry-response-to-fofa-legislation/, accessed 15 September 2011.

RWA (Rice Warner Actuaries) 2008, 'Value of Advice', Report for the Financial Planning Association, February 2008, http://www.72financial.com.au/pdf/valueofadviceresearch.pdf, accessed 3 October 2012. 
: 2012, 'Reforming the Age Pension', Touchstone magazine August 2012, http://www.ricewarner.com/images/newsroom/1346029730_Reforming\%20the\%20Age\%2 0Pension.pdf, accessed 3 October 2012.

Santacruz, L 2011, 'Dealer Group or Financial Planning Group? A Brief Technical Note', Australasian Accounting Business and Finance Journal, 5(2), 2011, pp. 127-134.

Sherry, N 2012, 'Some Challenges Facing Australia’s Defined Contribution (dc) Superannuation System', speech to the 20th Annual Colloquium of Superannuation Researchers, University of NSW, Sydney, 12-13 July 2012.

Siegel, LB 2008, 'Foreword', in Z Bodie, DW McLeavey \& LB Siegel (eds.), The Future of Life-Cycle Saving and Investing, $2^{\text {nd }}$ edition (February 2008), Research Foundation Publications, CFA Institute, pp. xiii-xv.

Smith, DK 2009, 'Regulating Investment Risk: Individuals and the Global Financial Crisis', UNSW Law Journal, 32(2), pp. 514-546.

Stewart, T 2014, 'FOFA changes won't hurt consumers: FSC', http://www.investordaily.com.au/35191-fofa-changes-won-t-hurt-consumers-fsc, accessed 30 July 2014.

St. John, R 2011, 'Review of compensation arrangements for consumers of financial services', Consultation Paper, http://futureofadvice.treasury.gov.au/content/consultation/compensation_arrangements_CP /downloads/Compensation_Consultation_Paper.pdf ,CCommonwealth of Australia.

Taylor, S \& Wagland, S 2011, 'Financial Literacy: A Review of Government Policy and Initiatives’, Australasian Accounting Business and Finance Journal, 5(2), 2011, pp. 101125.

Weatherhead, R 2009, 'How to measure the value of advice', Professional Planner, pp. 44-45.

Weber, M, Weber, EU \& Nosic, A 2011, 'Who Takes Risks When and Why: Determinants of Changes in Investor Risk Taking', 6 May 2011, Columbia Business School Research Paper No. 12/29, http://papers.ssrn.com/sol3/papers.cfm?abstract_id=1441273.

Widdowson, D \& Hailwood, K 2007, 'Financial literacy and its role in promoting a sound financial system', Reserve Bank of New Zealand Bulletin, vol. 70, http://www.rbnz.govt.nz/research_and_publications/reserve_bank_bulletin/2007/2007jun7 0_2widdowsonhailwood.pdf.

Wijetllake, S 2012, 'Gaining credit from the Financial Planning reforms: Winning the Trust and Generating New Fee Income with Clients', The Australian Journal of Financial Planning, Vol. 7, No. 1, 2012, pp. 23-26. 
Bruhn \& Miller | Best Interests Duty 